\title{
Amino Acid, Fatty Acid and Physico-Chemical Analyses of Jatropha curcas (Physic Nut) Seed Flour and Oil
}

\author{
O. Olaofe, F. J. Faleye*and J. A. Abey \\ Department of Chemistry, University of Ado-Ekiti P.M.B 5363 Ado-Ekiti Nigeria
}

\begin{abstract}
The amino acid of seed flour and fatty acid and physico-chemical analysis of oil both from Jatropha curcas (physic nut) seed were analytically determined. Amino acid results showed that the protein contained nutritionally useful quantities of most of the essential amino acids including sulphur-containing amino acids. The crude protein content was 34.2\%. The total essential amino acid (TEAA) with histidine was $32.7 \mathrm{~g} / 100 \mathrm{~g}$ while the TEAA without histidine was $30.6 \mathrm{~g} / 100 \mathrm{~g}$ protein. Glutamic acid (16.8 g/100g protein) was found to be the most abundant amino acid followed by aspartic acid (9.2 g/100g protein) in the seed flour. The seed oil of Jatropha curcas has a high crude fat content of $46.1 \%$ and a high proportion of total unsaturated fatty acid (40.8\%) with liloleic (18:2) as the most abundant unsaturated fatty acid while the total saturated fatty acid was $8.61 \%$ Palmitic acid (16:0), $8.6 \%$ was found to be the most abundant saturated fatty acid. The values for the physico-chemical properties of the extracted oil were: Acid value, (4.62 mgKOH/g), iodine value, (96.0 mgI $/ 2$ ), peroxide value, (6.22 $\mathrm{mgO}_{2} / \mathrm{g}$ ), saponification value, (219 $\mathrm{mg} \mathrm{KOH/g),} \mathrm{specific} \mathrm{gravity,} \mathrm{(0.89)} \mathrm{and} \mathrm{refractive} \mathrm{index,} \mathrm{(1.46),} \mathrm{These} \mathrm{results} \mathrm{suggest} \mathrm{that}$ Jatropha curcas is useful in some food formulations.
\end{abstract}

Key words: Jatropha curcas, Amino acid, Physicochemical analysis, Seed flour, Oil.

\section{Introduction}

Jatropha curcas (physic nut) is a drought resistant large shrub or small tree belonging to the family Euphorbiaceae. Physic nut tree thrives on a variety of soils and climatic conditions. It is unselective in soil requirements unlike most trees. It will not grow in marshy land, however it grows well on sandy soils or lateric soils. It thrives where other more sophisticated commercial crop trees would not (Heller, 1996). The seed of J. curcas becomes matured when the fruit changes from green to yellow. The colouration of the seed is fair black with a whitish cotyledon. A range of $33.6 \%$ to $34.5 \%$ of crude protein of $J$. curcas has been reported by Matana, et al. (2005). The oil of J. curcas is viscous, highly suitable for cooking, lighting by itself and useful in the production of biodiesel. The oil contains very little other components and has a very good quality for burning (Vaitiligon and Liennard, 1997).

It is well understood that the developing countries do not produce enough food with the correct nutritional quality to cater for the daily needs of the citizens and animals. In view

\footnotetext{
* Corresponding author: E-mail: fjfaleye2002@yahoo.com
}

of the teeming population being faced by these developing countries, J. curcas if utilized, will go a long way in eradicating the dearth in food supply and can be useful also in food industries for baby food and animal formulations. In order to introduce a new supplementation into any food items, it is important of determine whether the supplementation possesses the appropriate functional properties (Oshodi and Ekperigin, 1989) and is nutritionally good for consumer and industrial utiliation. Therefore, the present study presents the amino acid composition of the seed flour and fatty acid and physico-chemical analyses of $J$. curcas oil in order to exploit its potential in food formulations.

\section{Materials and Method}

The matured and diseased free $J$. curcas seeds were obtained from a garden in Oshogbo, Onward zone, Oshogbo Local Government, Osun State, Nigeria. The seeds were removed from the coat which contains a maximum of 3 seeds. It was dehulled and dry-milled into flour, packaged and stored until use. 


\section{Determination of Amino acid}

\section{Crude protein determination}

The crude protein was determined by the method described by Pearson (1976). Nitrogen content was determined by the micro-kjeldal method and the percentage nitrogen was converted to crude protein by multiplying by 6.25 .

\section{Defatting}

About $2.0 \mathrm{~g}$ of the sample was weighed into the extraction thimble and the fat extracted with $n$-hexane using a soxhlet extraction apparatus (AOAC, 1990). The extraction was lasted for $5 \mathrm{~h}$.

\section{Hydrolysis of sample}

A known weight (between 30 to $35 \mathrm{mg}$ ) of the defatted sample was weighed into glass ampoule. $7 \mathrm{ml}$ of $6 \mathrm{M} \mathrm{HCl}$ was added and oxygen was expelled by passing nitrogen into the ampoule in order to avoid possible oxidation of some amino acids during hydrolysis. The glass ampoule was then sealed with a bunsen flame and put into an oven present at $105^{\circ} \mathrm{C}$ for 22h. The ampoule was allowed to cool before breaking at the tip and the content was filtered to remove the humins.

The filtrate was then evaporated to dryness at $40^{\circ} \mathrm{C}$ under vacuum in a rotary evaporator. The residue was dissolved with $5 \mathrm{ml}$ of acetate buffer $(\mathrm{pH} 2.0)$ and stored in a plastic specimen bottle and kept in the deep freezer.

\section{Sample analysis}

The amino acid profile of the sample was determined using ion exchange chromatography (IEC) (FAO/WHO, 1991). The sample was loaded into the Technicon Sequential Multi Sample Amino Acid Analyser (TSM) manufactured by Technicon Instruments Corporation, New Youk. The TSM analyzer was designed to separate and analyse free acidic, neutral and basic amino acids of the hydrolysate.

\section{Determination of fatty acids}

The crude fat was determined by the extraction of oven dried sample in Soxhlet apparatus with $n$-hexane for $6 \mathrm{~h}$. Solvent was removed under reduced pressure in a rotary evaporator (AOAC, 1990).
Fatty acid methyl esters (FAMES) of the oil were prepared as reported by Akintayo (2004). The clear supernatant of the Fatty Acid Methyl Ester (FAME) was used for Gas chromatographic analysis. $0.2 \mathrm{ml}$ of the FAMES was injected into Hewlett- Packard 5890 GC (Hewlett-Packard Co, Palo Albo CA). The column was HP Ultra Performance coated with cross linked 5\% phenol $+95 \%$ polysiloxane, $30 \times 0.32 \mathrm{~mm}$, $0.5 \mathrm{~mm}$ coating thickness. Temperature programming was as follow: Initial temperature, $160^{\circ} \mathrm{C}$ for $3 \mathrm{~min}$, temperature increased at $8^{\circ} \mathrm{C} / \mathrm{min}$ up to $250^{\circ} \mathrm{C}$ and maintained at this final temperature for $5 \mathrm{~min}$. Injector and detector temperatures were $230^{\circ} \mathrm{C}$ and $275^{\circ} \mathrm{C}$, respectively.

\section{Physico-chemical analysis}

The physico-chemical analysis of the seed oil for acid value, iodine value, saponification value, peroxide value, specific gravity and refractive index, were carried out according to the methods of AOAC (1990).

\section{Results and Discussion}

Table I presents the amino acid profile of $J$. curcas protein flour. The flour of $J$. curcas has an average crude protein (34.2\%) which is higher than that of quinoa flour (13.5\%) reported by Ogungbenle (2003); lima bean flour (22.7\%) reported by Oshodi and Adelakun (1993) and of pigeon pea (22.4 \%) reported by Oshodi and Ekperigin (1989). The value is however lower than scarlet runner bean flour (65.2\%) reported by Aremu et al. (2005). The high crude protein content of $J$. curcas makes it a good source of protein which could be used as feeds in live stocks.

Leucine is the most highly concentrated essential amino acid ( $6.5 \mathrm{~g} / 100 \mathrm{~g}$ protein). The value compared very well with the value obtained for protein concentrate of Anarcadium occidentale (6.2 g/100 g protein) (Aremu et al., 2007). However, the value is lower than that obtained for protein concentrates of some Nigerian legumes; lima bean (7.59 g/100 g protein); pigeon pea (8.40 g/100 g protein) and African yam bean (7.45 g/100 g protein) (Oshodi et al., 1993). It is observed that aspartic and glutamic acids together make up (26.1 $\mathrm{g} / 100 \mathrm{~g}$ protein)and are the most abundant amino acids in the plant food sample. Similar observation has been reported by Olaofe and Akintayo (2000) and Adeyeye (2004). The least 
Table I: Amino acid composition (g/100g crude protein) of $J$. curcas flour

\begin{tabular}{l|c}
\hline Amino acid & g/100g protein \\
\hline Leucine*(Leu) $^{*}$ & 6.5 \\
Isoleucine*(Ile) & 3.0 \\
Lysin*(Lys) & 3.4 \\
Methionine*(Met) & 0.7 \\
Valine*(Val) & 3.9 \\
Threonine*(Thr) & 3.6 \\
Phenylalanine *(Phe) & 4.6 \\
Arginine* (Arg) & 4.9 \\
Histidine* (His) & 2.1 \\
Alanine (Ala) & 4.2 \\
Glycine (Gly) & 3.0 \\
Serine (Ser) & 4.2 \\
Proline (Pro) & 3.6 \\
Cysteine (Cys) & 1.5 \\
Tyrosine (Tyr) & 3.5 \\
Glutamic acid (Glu) & 16.8 \\
Aspartic acid (Asp) & 9.2 \\
Tryptophan (Try) & N.D \\
\hline
\end{tabular}

*Essential amino acids

N.D- Not Determined

amino acid is methione (0.65 g/100 g protein), which is lower in comparison with that of cashew nut $(1.7 \mathrm{~g} / 100 \mathrm{~g}$ protein) (Aremu et al., 2007).

The nutritive value of a protein depends primarily on the capacity to satisfy the needs for nitrogen and essential amino acids. The total essential amino acids (with histidine) of $J$. curcas protein flour (32.7 g/100 g protein) as shown in Table II, compared very well with that of Prosopis africana concentrate (31.9 g/100 g protein) reported by Aremu et al. (2007). However, it is less than those reported by Oshodi et al. (1998), for lima bean (44.8g/100 g protein); pigeon pea (48.1g/100 protein) and African yam bean (48.3g/100g protein). The total Acidic Amino Acid (TAAA) (26.1 g/100 protein) is greater than the total Basic Amino Acid (TBAA) (10.4 g/100 g protein), indicating that $J$. curcas protein is probably acidic in nature.
Table II: Classification of amino acid composition (g/100g crude protein) of $J$. curcas flour

\begin{tabular}{l|c}
\hline Classification & $\begin{array}{c}\text { Concentration } \\
\text { (g/100 g protein) }\end{array}$ \\
\hline Total amino acids (TAA) & 78.7 \\
Total Essential amino acids with Histidine & \\
(TEAA) & 32.7 \\
Total Essential amino acids without Histidine & 30.6 \\
\% Total Essential amino acids with histidine & 41.5 \\
\% Total Essential amino acids without histidine & 38.9 \\
Total Non-Essential amino acids (TNEAA) & 46.0 \\
\%TNEAA & 58.5 \\
Essential aromatic amino acids (EArAA) & 4.63 \\
\%EArAA & 5.9 \\
Total acidic amino acids (TAAA) & 26.1 \\
\%TAAA & 33.1 \\
Total Basic amino acids (TBAA) & 10.4 \\
\%TBAA & 13.2 \\
Total Neutral amino acids (TNAA) & 42.2 \\
\%TNAA & 53.6 \\
Total Sulphur amino acids (TSAA) & 2.2 \\
\%TSAA & 2.8 \\
\%Cystine in TSAA & 1.9 \\
\%EAA in TAA & 41.6 \\
\hline
\end{tabular}

The Total Sulphur Amino Acid (TSAA) of the sample was $2.2 \mathrm{~g} / 100 \mathrm{~g}$ protein, which is close to halve the value (5.8 $\mathrm{g} / 100 \mathrm{~g}$ protein) recommended for infants (FAO/WHO/UNU, 1985). The aromatic amino acid (ArAA) range suggested for ideal infant protein (6.8-11.8 g/100 g protein) (FAO/WHO/UNU, 1985) is much higher than the current report (4.63 g/100 g protein) indicating that J. curcas flour could be used to prepare gruel as weaning food, it should be supplemented with ArAA rich foods. The percentage ratio of EAA to TAA in the flour was 41.6. This value was well above the $39 \%$ considered to be adequate for ideal protein food for infants, $26 \%$ for children and $11 \%$ for adults (FAO/WHO/UNU, 1985). the percentage of EAA/TAA for $J$. curcas flour could be favourably compared with that of pigeon pea flour (43.6\%) (Oshodi et al., 1993), beach pea protein isolates (43.8-44.8\%) (Chavan et al., 2001). The amino acid profile of the studied plant seed suggests that its protein has moderate nutritive value.

Table III shows that fatty acid composition of J. curcas oil. The oil has a high crude content of $46.1 \%$. This value is lower than that of Plukenetia conophora seed oil (49.6\%) 
and Adenopus breviflorus seed oil (56.2\%) as reported by Akintayo and Bayer (2002). J. curcas seeds are however better sources of oil than Bombcapsis glabra seeds (34.8\%) reported by Olaofe et al. (2006) and soy bean (23.5\%) reported by Paul and Southgate (1985). The present value compares very well with that of Cucumeropsis edulis (43.7\%) reported by Ige et al. (1984) and pumpkin seed (47\%) reported by Aisegbu (1987).

Table III. Components fatty acid of $\boldsymbol{J}$. curcas oil

\begin{tabular}{l|c}
\hline Fatty acid & Concentration \\
\hline Crude Protein & 34.2 \\
Crude Fat & 46.1 \\
Myristic $\mathrm{C}_{14: 0}$ & 0.01 \\
${\text { Palmitic } \mathrm{C}_{16: 0}}$ & 8.6 \\
Oleic $\mathrm{C}_{18 \mathrm{~L}: 1}$ & 4.37 \\
Linoleic $\mathrm{C}_{18: 2}$ & 34.6 \\
Linolenic $\mathrm{C}_{18: 3}$ & 1.79 \\
Total saturated fatty acid & 8.61 \\
Total unsatruaed fatty acid & 40.8 \\
\hline
\end{tabular}

Linoleic acid $\left(\mathrm{C}_{18: 2}\right)$ which is one of the most important polyunsaturated fatty acids in human diet because of its prevention of distinct heart vascular disease (Boelhouwer, 1983), is the most abundant fatty acid with a percentage composition of 34.6. The percentage unsaturation in the oil of $J$. curcas was $40.8 \%$ with total essential amino acids (linoleic and linolenic) of $36.4 \%$.

Fats are important part of the infant's diet because they are vital to the development of the nervous system. As a concentrated source of calories, fat also helps resolve the potential problems of the infant's high calorie needs and small stomach capacity (Wardlaw, 2007). It is well known that dietary fats rich in linoleic acid prevent cardiovascular disorders such as coronary heart diseases, arteriosclerosis and high blood pressure and also that linoleic acid derivatives serve as structural components of the plasma membrane and as precursors of some metabolic regulatory components (Vles and Gottemborg, 1989).

Saturated fatty acids; lauric $\left(\mathrm{C}_{12: 0}\right)$, myristic $\left(\mathrm{C}_{14: 0}\right)$ and palmitic $\left(\mathrm{C}_{16: 0}\right)$ have been established as the most important of the dietary risk factors (Bender, 1992). High level of total blood cholesterol is associated with the incidence of high intake of saturated fatty acid (Bender, 1992).
The physico-chemical characteristics of the seed oil of $J$. curcas are presented in Table IV. The specific gravity of 0.89 of the oil indicates that it is less dense than water. The light yellow oil has an acid value of $4.62 \mathrm{mg} \mathrm{KOH} / \mathrm{g}$. This value is higher than those reported for oil of bean seeds with the value $2.77 \mathrm{mg} \mathrm{KOH} / \mathrm{g}$ and $2.74 \mathrm{mg} \mathrm{KOH} / \mathrm{g}$ (Ekpa and Ekpe, 1995). J. curcas oil had low acid value when compared with Plukenetia conophora (11.5 mg KOH/g) (Akintayo and Bayer, 2002); Bilphia sapida oil (14.2 mg KOH/g) (Akintayo et al., 2002); beniseed (47.6 mg KOH/g) (Oshodi, 1992).

The refractive index of 1.46 of $J$. curcas oil shows that the oil is thicker than most drying oils, such as linseed oil, soybean oil and cod liver oil (with refractive indices between 1.48 and 1.49) (Duel, 1951). The oil has high iodine value (96 $\mathrm{mgI}_{2} / \mathrm{g}$ ) when compared with Citrulus vulgaris (38.5 $\mathrm{mgI}_{2} / \mathrm{g}$ ) (Oladimeji et al , 2001) and Bilphia sapida oil (65.4 $\mathrm{mgI}_{2} / \mathrm{g}$ ) (Akintayo et al., 2002). The iodine value of J. curcas oil places it in the semi-drying oil group. This iodine value suggests the use of the oil in production of alkyd resin, shoe polish, vanishes etc. The saponification value (219 mg $\mathrm{KOH} / \mathrm{g}$ ) of $J$. curcas oil is higher than those reported for Plukenetia conophora (92.2 mg KOH/g); Adenopus breviflorus (190 mg KOH/g) (Akintayo and Baeyer, 2002); cotton seed oil (190-200) and soybean (190-194) but compares favourably with butter fat (220-240) and coconut oil (200250) reported by Paul and Southgate (1985).

Table 4: Physico-chemical properties of $\boldsymbol{j}$. curcas oil

\begin{tabular}{l|c}
\hline Parameter & Value \\
Colur & Light yellow \\
Specific gravity & 0.89 \\
Refractive index & 1.46 \\
Acid value mg KOH/g & 4.62 \\
Saponification value mg KOH/g & 219 \\
Iodine value $\mathrm{mgI}_{2} / \mathrm{g}$ & 96 \\
Peroxide value $\mathrm{mg}$ reac. O2g-1 & 6.22 \\
\hline
\end{tabular}

\section{Conclusion}

$J$. curcas is a good source of protein with a high crude protein content of $34.2 \%$ as revealed in this study. High essential amino acid of the protein with abundant unsaturated fatty acid of the oil of $J$. curcas enhances its potentiality in human and animal food formulations. The results further showed that the seed oil of J. curcas has high iodine and saponifica- 
tion values with low acid value. These qualities therefore suggest its use in soap and paint industries.

\section{Acknowledgement}

The authors sincerely appreciate Dr. T. Ojobe of University of Jos and Mr. A.A. Bello for the technical assistance rendered in the analyses of amino acids and fatty acids respectively.

\section{References}

Adeyeye E. I. (2004). The chemical composition of liquid and solid endosperm of ripe coconut. Oriental $J$. Chem., 20: 471-478.

Aisegbu E. I. (1987). Some biochemical evaluation of Fluted pumpkin seeds. J. Food Sci. Agric., 40: 151.

Akintayo E. T. and Baeyer E. (2000). Characterisation and some possible uses of Phikenetia conophora and Adenopus breviflours seeds and seed oils. Bioresource Technology, 85: 95-97.

Akintayo, E. T., Adebayo E. A. and Arogundade L. A (2000). Chemical composition, physicochemical and functional properties of akee (Bilphia sapida) pulp and seed flours. Food Chemistry, 77: 333-336.

Akintayo E. T. (2004). Characteristics and composition of Parkia biglobbossa and Jatropha curcas oils and cakes. Bioresource Technology 92: 307-311.

Aremu M. O., Ogunlade I. and Olonisakin A. (2007). Fatty acid and amino acid composition of protein concentrate from cashew nut (Anarcadira occidentali) growing in Nassarawa State, Nigeruia. Pakistan J. Nutrition, 65: 419-423.

Aremu M. O., Olaofe O. and Akintayo E. T. (2006). Compositional evaluation of cowpea (Vigna unquiculata) and scarlet runner bean (Phaseolus coccineus) varieties grown in Nigeria. J. Food Agric. Environment. 4(2): 39-43.

AOAC (1990). Official methods of analysis, 15th Edn., Washington DC. Association of official Analytical Chemist.
Bender A. (1992). Meat and meat products in human nutrition in developing countries. FAO, Food and Nutrition, paper 53. FAO, Rome, pp 47-50.

Boelhouwer C. (1983). Trends in Chemistry and Technology of lipids. J. Am. Oil Chem. Soc. 60(2): 457-462.

Chavan U. D, Mckenzie D. B. and shahidi F. (2001). Functional properties of proteins isolates from beach pea (Lathyrus maritimus L.) Food Chem. 74: 177-187.

Duel H. J. Jr. (1951). The lipids: their chemistry and biochemistry vol. 1. New York. Inter-science Publishers.

Ekpa O. D and Ekpe U. J. (1995). The effect of coconuts oil concentrate and air exposure to the total acidity of paim oil. Global J. Pure \& Applied Sci., 1(1/2): 51-58.

FAO/WHO/UNU (1985). Energy and Protein Requirements. WHO. Technical series No. 724, WHO; Geneva, pp 13205.

Ige M. N., Ogunsua A. O. and Oke O. L. (1984). Functional properties of the proteins of some Nigerian oil seeds. Food Chem., 32: 822.

Ogungebenle H. N. (2003). Nutritional evaluation and functional properties of quinoa (Chenopodium quinoa) flour. In J. food Sci. Nutr., 54: 153-158.

Olaofe O., Akintayo E. T., Adeyeye E. I and Adubiaro H. O. (2006). Proximate composition and Functional properties of Bulma cotton (Bombcapsis glabra) seeds. Egypt J. food Sci., 34: 81-90.

Olaofe O. and Akintayo E. T. (2000). Prediction of isoelectric points of legume and oilseed proteins from their amino acid composition. Technoscience, 4: 48-53.

Oshodi A. A. (1992). Proximate composition, nutritionally valuable minerals and functional properties of Adenopus breviflorus benth seed flour and protein concentrate. Food chemistry, 45: 79-81.

Oshodi A. A. and Adelakun M. O. A. (1993). Proximate composition, some valuable minerals and functional properties of three varieties of lima bean flour. Int. $J$. Food Sci. Nutr., 43: 181-185. 
Oshodi A. A. and Ekperigin M. M. (1989). Functional properties of pigeon pea (Cajanus cajan) flour. Food Chem., 34: 187-191.

Oshodi A. A., Olaofe O. and Hall G. M. (1993). Amino acid, fatty acid and mineralt composition of pigeon pea (Cajanus cajan). Int. J. Food Sci. Nutr., 43 : 187-191

Oshodi A. A., Esuoso K. O., and Akintayo E. T. (1998). Proximate and amino acid composition of some underutilized Nigerian legume flour and protein concentrates. La Rivista Italiana delle Sostanse grasse, 75: 409-412.

Paul A. A. and Southgate D. A. T. (1985). McCance and Widow-son's The composition of Foods'. London: Royal Society of Chemistry.
Vaitilingom G. and Liennard A. (1997). In : Gubitz G.M., Mittelbach M., Trabi M. Biofuels and industrial products from Jatropha curcas $=$ [Prioduits industries et biocarburants issus de Jatropha curcas]. Graz : Gubitz, pp. 98-109. Symposium Jatropha 97,1997-02-23/1997-0227, (Managua, Nicaragua).

Vles R. O. and Gottemborg J. J. (1989). Nutritional characteristics and food uses of vegetable oils. In oil crops of the world, G. Robbelen, R.K. Downey, A. Ashri editors McGraw Hill, New York pp. 63-86.

Wardlaw G. M. and Smith A. M. (2009). Contemporary Nutrition. Seventh Edition. McGraw Hill, New York, pp. 163-199.

Received : September 02, 2009;

Accepted : February 25, 2010 